DOI: 10.2478/atd-2020-0024

\title{
Structured, Analytical and Critical Thinking in the Educational Process of Future Teachers
}

\author{
Pavel Beňo - Patrik Havan - Sandra Šprinková ${ }^{*}$
}

Received: April 26, 2020; received in revised form: June 7, 2020;

accepted: June 9, 2020

\begin{abstract}
:
Introduction: In this article, we want to point out what kind of pedagogical and didactic change is being recorded in Slovakia's education system and we will point out where it could go and develop to achieve positive results. This article is one of the upcoming outputs in the form of paper and study on the provision of structured, analytical and critical thinking (SAC). In the article, it is shown how the situation has changed and how we perceive the attitude of students during the educational process. Next, it is described current problems and inadequacies in the educational process and define how to use a change of thinking to increase motivation and improve access to knowledge.

Purpose: In general, there is a consensus that it is important for teachers to be able to guide their students to problem-solving skills (Aktaş \& Ünlü, 2013). It is pointed out that, with the right educational tools, such skills can be stimulated, developed and improved (Jordaan \& Jordaan, 2005). This article is designed for all levels of education, but we are mostly concerned with educating future educators.

Methods: In this paper, there are described methods that can help to improve the quality of thinking of students and thus increase the level of thinking of the whole society. This article take inspiration from important historical personalities as well as relevant current personalities in their professions. Critical, analytical and creative thinking, also based on logical and structured thinking, is our main method of our educational process.

Conclusion: In conclusion, it is pointed out the need to develop SAC as a whole. It is important for the general publica to have better skills in SAC, for example, from the point of view of cognitive mistakes in experts, in the field of political literacy, recognition of misinformation and a better general awareness of rational thinking. As can be seen, SAC is not only about education, but it also closely affects society as a whole. It can thus
\end{abstract}

\footnotetext{
* Pavel Beňo, Trnava University in Trnava, Trnava, Slovakia; pavel.beno@truni.sk; Patrik Havan, Trnava University in Trnava, Faculty of Philosophy, Trnava, Slovakia; patrik.havan@tvu.sk Sandra Šprinková, Trnava University in Trnava, Faculty of Education, Trnava, Slovakia; sandra.sprinkova@tvu.sk
} 


\title{
Acta Educationis Generalis \\ Volume 10, 2020, Issue 3
}

\begin{abstract}
influence the operation of the company, prevent the development of the first-class solutions offered and raise the whole company to a higher level.
\end{abstract}

Key words: structural, analytic and critical thinking, education, pedagogy.

\section{Introduction}

It is perceived that once, when a person encountered an engineer or a generally university-educated person, he was more likely to find a suitable topic with him. Most people with university education had an overview of what was happening in society and were able to evaluate it constructively. Today, however, it is perceived the situation differently. There is an incredible number of universityeducated people, but from our personal experience, often (honouring exceptions), it is difficult to find common language, discussion, argument and solutions. Why is this so? This article tries to find the answer, where is considered the way that teaching thinking can be beneficial for the general perception of young people as well as to increase their interest in public affairs. As participants in the educational process often find that students are described as uneducated, slack and especially irrational even in the circles of educators. It can be perceived that students often lack the motivation to learn. The society can ask whether educators should provide motivation for education alone, or it is a more complex problem reflecting their previous life experience with education. Also, our knowledge come from personal experience that students spent days and nights in labs and study rooms but nowadays these premises are empty. Where did the enthusiasm for education and achievement disappear? Perhaps the society have stopped teaching children and young people in a way that make them to think. Current generations discover information on the Internet and do not even think about whether the information is relevant or not (Šnídl, 2017). Even a lay society perceives the consequences of a wealth of information that overwhelms people and specifically the young. One of the consequences of the previous mentioned matter may also be a decrease in logical thinking. Logical thinking in this context can be defined as developed thinking such as analytical, structured and critical thinking (SAC). That is why it is important that the central issue of teaching future teachers is to support the development of thinking. Improvement of thinking could be caused also by using a multimedia educational materials and technologies (Hrmo, Miština, \& Krištofiaková, 2016). Nowadays, we unfortunately see that the PASCAL programming language is still being taught in schools, which is mistakenly described as the bearer of the idea of teaching students to think in a structured way. This could be done if we disregard more factors. Since there is no research in this area yet, we infer at least from our experience and student feedback. Firstly, students consider PASCAL to be unnecessary and do not intend to pursue it because they do not see its applicability in their further practice. Secondly, they do not intend to learn 


\section{Acta Educationis Generalis \\ Volume 10, 2020, Issue 3}

a programming language just to learn algorithmization, and thirdly, most strikingly, students are trying to pursue such a subject rather than focus on it. This causes them to twist two semesters somehow, and thus the whole development of thinking is equipped. According to us, it would be appropriate to find ways to change this situation. It is not only two semesters at university, but the whole society need a change. Indeed, such future educators who only completed this whole learning how to teach process will teach the new generation. Let's ask a question. How will they educate students? (Ballová Mikušová, 2019).

\section{Purpose}

In general, it is important that teachers have problem-solving skills and that they also lead their students to such skills (Aktaş \& Ünlü, 2013). Jordaan and Jordaan (2005) argue that, with the right educational tools, such skills can be stimulated, developed and improved. It can be seen that the development of such skills is a challenge for the whole society, but especially for experts in relevant fields to find such educational tools and for them to be further applied in education.

It is necessary to lead students; to follow and consciously guide their thinking (we use the same procedures for example in teaching wushu, a Chinese martial art - author's comment). As students become aware of the ways they used to think, they become more autonomous in their own learning process. Zero Project at Harvard University (Ritchhart \& Perkins, 2020) suggests that when students learn practices to develop thinking, it deepens. Ritchhart and Perkins (2020) utilize thought processes that are routinely reused (Kahneman, 2011; Tay, Ryan, \& Ryan, 2016), a little like the Confucian Teaching Method (Tan, 2017).

We consider to be important to capture the development of thinking already in secondary and elementary schools and also to create the foundations of thinking in pre-elementary preparation of children in order to establish the habit of thinking more analytically and making decisions.

\section{Methods}

The aforementioned methods aimed at a group of students can also be important for the emergence of creative thinking. Creative thinking is a cognitive process; respectively, the creation of ideas that are often not as new as people might think, but most of all it is about realizing new connections between existing concepts. In this way, we or our students do not have to come up with a groundbreaking invention, but we can, on an elementary level, follow daily tasks and think about how to do them better. The authors encourage the creation of processes that allow and reward spontaneity and improvisation, thus promoting systemic change in thinking and, therefore, more effective student access to the learning process. We also consider it necessary to create a common vision for students, thus keeping the teaching process in a systematic and chosen structure 


\section{Acta Educationis Generalis \\ Volume 10, 2020, Issue 3}

and avoiding the chaos that could occur immediately, if we do not do the needed arrangements. We also encourage the implementation of team tasks in the educational process. Let's give teamwork tasks, even though we do not want to get rid of things like learning with PASCAL. Let's change the tasks so that students are made to work together so that all the work on the project is not left to just one team.

Analytical thinking is one form of logical thinking and reasoning. It begins to manifest already in childhood and therefore it is well developed from an early age. However, analytical thinking is not only about mathematics, as is the frequent connotation of the term in the general population but is a process where one thing follows the other. As the name says, analytical thinking involves analysis. The analysis is an analysis of the whole problem, an examination of the individual aspects, and a selection of important information so that the smaller parts are eventually combined into larger ones and then to the resulting solution. It is therefore important to require analytical thinking from students to be able to quickly process a lot of changing information.

Critical thinking is an interdisciplinary issue. It is an area of scientific interest for a number of disciplines, for example in psychology, economics and also pedagogy (Frederick, 2005; Kahneman, 2011; Fahim \& Eslamdoost, 2014; Toplak, West, \& Stanovich, 2014; Čavojová, 2016; Tay, Ryan, \& Ryan, 2016; Čavojová \& Jurkovič, 2017). Fahim and Eslamdoost (2014) define critical thinking as a justification; a scientific and analytical method of problem solving, gaining evidence, arguments and knowledge. Today, rapid reactions and responses are often required, but often lead to erroneous decisions. The second way of thinking and making decisions - critical thinking - is slower but can lead to better results. In this way, the academic community in research often nowadays operates in thought - to think fast and slow (critical), or to system 1 and system 2 (Frederick, 2005; Kahneman, 2011; Čavojová, 2016). In research, the Frederick (2005) method is usually used to measure the level of critical thinking, which includes items that are automatically attacked by an inaccurate, intuitive answer (system 1/thinking fast), but when the student knows the correct answer, he perceives it as easy and logical. The basis is that the respondent must not be influenced by system 1, must not automatically respond, but instead use critical thinking (system 2/slow thinking). As an example, the question is: "If 5 machines take 5 minutes to produce 5 devices, how long will 100 machines take 100 devices?" The answer that, according to theory, system 1 is 100 minutes, system 2, or critical thinking this catcher will reveal. The correct answer is of course 5 minutes (Frederick, 2005).

In this case, system 1 plays the role of cognitive impulsivity and laziness which is the result of automatic thinking. System 1 is reflective, experiential, intuitive and automatic and accompanied by the absence of a sense of deliberate control. It is usually active when problems and tasks are routine and not surprising. As an example, Frederick (2005) used to recognize the face of a well-known person 


\section{Acta Educationis Generalis \\ Volume 10, 2020, Issue 3}

who entered the room when we expect it. System 2 plays the role of critical thinking - judgment and cognitive processing capabilities and is more complex and rational. However, System 2 is slower and requires more cognitive effort, but in more complex situations it is likely to lead to better decisions (Frederick, 2005; Kahneman, 2011; Toplak, West, \& Stanovich, 2014; Čavojová, 2016; Stoker, Hay, \& Barr, 2016; Tay, Ryan, \& Ryan, 2016; Ballová Mikušová, 2019). As an example of a situation where system 2 is involved, Frederick (2005) used a more complicated mathematical example (e.g. 53). To distinguish how system 1 and system 2 work, we can give another example. For example, if a politician today talks about complex, economic solutions that the voter simply cannot understand, instead of asking basic, relevant questions such as: "Is he telling the truth? "; "Does he provide solutions or just scream buzz words?", which System 2 would ask, System 1 employs a simpler approach: "Do I find the politician sympathetic?"; "Do his words fit with my beliefs?" (Kahneman, 2011). However, although System 1 may sound negative and harmful from these sources, this is not entirely true. Both systems have their place in human life, depending on situations and circumstances (Kahneman, 2011; Tay, Ryan, \& Ryan, 2016).

Although critical thinking is often discussed today, it is not new. After all, Socrates introduced the so-called Socratic interview (Krošlák, 2012) where he examined assumptions and sought evidence, analysed the statements and uncovered contradictions. It is not surprising that critical thinking, although they did not call their studies so directly, was also employed by such personalities as Darwin (Darwin, 1887), Machiavelli (Harrison, 2009), Leonardo da Vinci (Armentano \& Kun, 2019), and Thomas Aquinas (Dancák, 2016). In general, critical thinking can be defined as the ability to create one's own opinion based on the experience and knowledge gained. We will discuss this further in upcoming study and explain why not to deal with only one categorized way of thinking. Both methods of thinking begin with raising questions about the problem.

\section{Conclusion}

Critical thinking is particularly important in making good decisions in more challenging situations, including experts in their field (Frederick, 2005; Kahneman, 2011; Tay, Ryan \& Ryan, 2016). They can automate the operations over time, making their work more efficient over time, but this can also result in various cognitive and inferior errors. Kahneman (2011) cites as a real example judges who decided on punishments differently based on whether they were hungry (it was the time just before lunch) or not. Critical thinking also has an impact on the perception of social and political issues (Stoker, Hay \& Barr, 2016). Critical thinking, along with analytical thinking, can also serve as a defence against the unsubstantiated beliefs, myths and fake news to which we are now frequently exposed (Šnídl, 2017; Ballová Mikušová, 2019; Jurkovič, 


\section{Acta Educationis Generalis \\ Volume 10, 2020, Issue 3}

2019; Šrol, 2019) and to which we are likely to be ever more frequently exposed in the future. Critical and creative thinking are also important abilities for finding place in labour market (Bajtoš, Lajčin, \& Gabrhelová, 2020).

The main difference between critical and uncritical thinking is that uncritical, non-analytical and unstructured thought is not evaluated, estimated and carefully assumed, but is purely irrational and accompanied by a passive assumption (Kahneman, 2011). Building better thinking is a long-term process and leads to sufficient reflection and self-reflection (Bašnáková, 2019). With a greater degree of such thinking, one can better form one's own opinion, understand historical contexts, evaluate art and literature, link economic and political contexts, and, most importantly, work in a team and be flexible in times of rapid change.

Firstly, we wanted to point out in this article the need for a change in the teaching process. There is a specification that it should be mainly universities where future educators are educated, but such a specification would be shortsighted. The truth is that thought must be given a lot of attention, not only in education, whether high, secondary or elementary, but it must be dealt with in a flatrate way so that the nation is not subjected to the misinformation and illusions presented to them.

Of course, we do not consider this paper to be the result of our efforts. We will also try to create a study in which we will show how the education process really is within the Slovak education system. We will continue to point out the need for developing education, not the flatten ability of higher education degrees, the need to teach people to think critically and not to be false. Although the scientific community is largely engaged in critical thinking (Frederick, 2005; Aktaş \& Ünlü, 2013; Fahim \& Eslamdoost, 2014; Toplak, West, \& Stanovich, 2014; Čavojová, 2016; Stoker, Hay, \& Barr, 2016; Tay, Ryan \& Ryan, 2016; Čavojová \& Jurkovič, 2017), we would also recommend future researchers to focus on this factor in the context of education which we have tried to explore a little in this article.

\section{References}

Aktaş, G. S., \& Ünlü, M. (2013). Critical thinking skills of teacher candidates of elementary Mathematics. Social and Behavioral Sciences, 93, 831-835. https://doi.org/10.1016/j.sbspro.2013.09.288

Armentano, R. L., \& Kun, L. (2019). Leonardo da Vinci - The first bioengineer: Educational innovation to meet his desire for knowledge and promote his concept of interdisciplinarity. Creative Education, 10(6), 1180-1191. https://doi.org/10.4236/ce.2019.106089

Bajtoš, J., Lajčin, D., \& Gabrhelová, G. (2020). Teaching professional technical subjects accepting current trends in field didactics. Acta Educationis Generalis, 10(1), 81-97. https://doi.org/10.2478/atd-2020-0006 
Ballová Mikušová, E. (2019). Redukovanie nepodložených presvedčení pomocou kritického myslenia. In M. Jurkovič, V. Čavojová, \& I. Brezina (Eds.), Prečo l'udia veria nezmyslom (pp. 165-182). Bratislava: Premedia.

Bašnáková, J. (2019). Múdre deti: ako sa vyvíjajú kritické myslenie a vedecké myslenie. In M. Jurkovič, V. Čavojová, \& I. Brezina (Eds.), Prečo lúdia veria nezmyslom (pp. 217-245). Bratislava: Premedia.

Čavojová V., \& Jurkovič M. (2017). Racionálni učitelia a intuitívni manažéri: Interakcia veku a kognitívnej reflexive pri rozhodovaní. In Kognícia a umelýživot (pp. 30-37). Bratislava: Univerzita Komenského v Bratislave.

Čavojová, V. (2016). Good things do not happen to me.. but neither do the bad things: Comparative optimism and pessimism in a slovak sample. Studia Psychologica, 58(4), 286-306. https://doi.org/10.21909/sp.2016.04.724

Dancák, P. (2016). Disputationes quodlibetales. In Ludské konanie vo filozofickej reflexii Tomáša Akvinského (pp. 6-18). Prešov: Prešovská Univerzita $v$ Prešove.

Darwin, C. (1887). The autobiography of Charles Darwin. Collins.

Fahim M., \& Eslamdoost S. (2014). Critical thinking: Frameworks and models for teaching. English Language Teaching, 7(7), 141-151. https://doi.org/10.5539/elt.v7n7p141

Frederick, S. (2005). Cognitive reflection and decision making. Journal of Economic Perspectives, 19(4), 25-42. https://doi.org/10.1257/08953300 5775196732

Harrison, R. P. (2009). What can you learn from Machiavelli? Retrieved from https://insights.som.yale.edu/insights/what-can-you-learn-machiavelli

Hrmo, R., Miština, J., \& Krištofiaková, L. (2016). Improving the quality of technical and vocational education in Slovakia for European labour market needs. International Journal of Engineering Pedagogy, 6(2), 14-22. https://doi.org/10.3991/ijep.v6i2.5369

Jordaan, A., \& Jordaan, D. (2005). A logical and structural thinking development tool (LST) to enhance fundmental problem-solving skills of learners of information technology. The Journal of Trandisciplinary Research in Southern Africa, 1(1), 59-76. https://doi.org/10.4102/td. v1i1.303

Jurkovič, M. (2019). Predslov. In M. Jurkovič, V. Čavojová, \& I. Brezina (Eds.), Prečo l'udia veria nezmyslom (s. 7-11). Bratislava: Premedia.

Kahneman, D. (2011). Myšleni rychlé a pomalé (Vol. 1). Brno: Jan Melvil Publishing.

Krošlák, D. (2012). Sokratovská metóda ako pedagogická forma v procese vzdelávania právnikov. Exemplo ducti, 184-195. Retrieved from https://www.academia.edu/9899337/Sokratovsk\%C3\%A1_met\%C3\%B3da ako_pedagogick $\% \mathrm{C} 3 \% \mathrm{~A} 1$ _forma_v_procese_vzdel $\% \mathrm{C} 3 \% \mathrm{~A} 1 \mathrm{~A}$ ania_pr $\% \mathrm{C}$ 3\%A1vnikov 


\section{Acta Educationis Generalis \\ Volume 10, 2020, Issue 3}

Ritchhart, R., \& Perkins, D. (8. 3 2020). Harvard: Project Zero. Retrieved from http://www.pz.harvard.edu/

Stoker, G., Hay, C., \& Barr, M. (2016). Fast thinking: Implications for democratic politics. European Journal of Political Research, 55(1), 1-19. https://doi.org/10.1111/1475-6765.12113

Šnídl, V. (2017). Pravda a lož na Facebooku (Vol. 1). Bratislava: N Press.

Šrol, J. (2019). Čo sú to nepodložené presvedčenia a prečo im l’udia veria? In M. Jurkovič, V. Čavojová, \& I. Brezina (Eds.), Prečo l'udia veria nezmyslom (s. 12-49). Bratislava: Premedia.

Tan, C. (2017). Confucianism and Education. https://doi.org/10.1093/acrefore/ 9780190264093.013.226

Tay, S. W., Ryan, P., \& Ryan, C. A. (2016). Systems 1 and 2 thinking processes and cognitive reflection testing in medical students. Canadian Medical Education Journal, 7(2), 97-103.

Toplak, M. E., West, R. F., \& Stanovich, K. E. (2014). Assesing miserly information processing : An expansion of the Cognitive Reflecton Test. Thinking \& Reasoning, 20(2), 147-168. https://doi.org/10.1080/13546783. 2013.844729 